\title{
Investigating Society: The Cases of Pepe Carvalho and Tito Ihaka
}

\author{
CAROLINA MIRANDA AND BARBARA PEZZOTTI
}

\section{Introduction}

This article seeks to draw some parallels between two crime novels: Murder in the Central Committee (1981) by Spanish author Manuel Vázquez Montalbán ${ }^{1}$ and Old School Tie (aka Dirty Laundry, 1994) by New Zealand author Paul Thomas. ${ }^{2}$ Despite their different background and the epochs in which they write, we will argue that these writers share some important features. First of all, they are both influenced by the hardboiled genre and therefore, they give accounts of modern, cosmopolitan societies (mainly Barcelona and Auckland), ${ }^{3}$ and both exploit political incorrectness. Second, their detectives have contempt for authority, speak their minds, are equally at ease amongst the bourgeoisie or the working class, and know their city extremely well. Finally, and most importantly, both series reflect a renegotiation of national identity in a multicultural context. In the case of Vázquez Montalbán, the focus is on the dialectic between national and regional, present and past, while with Thomas's series the focus is on Māori and Pākehā. ${ }^{4}$ However, both writers defy mainstream interpretations of these dialectics as seen in crime fiction so far. They give a different perspective, going beyond simplistic contrapositions or polarizations. In so doing, they demand that readers go beyond stereotypes and analyze the question of cultural identity in all its complexity.

Questions of identity have traditionally been central to crime fiction. The initial search for a single identity - the culprit in the so-called 'whodunit' - has been gradually expanded into an investigation of society at large. If the classic whodunit mainly depicts an unproblematic society where crime is a mere incident, the subsequent hardboiled subgenre is characterized by more realism. As Margaret Crawford has highlighted, the passage from an enclosed room to the mean streets of the modern metropolis now reflects the tensions and problems of contemporary society. ${ }^{5}$ According to Marieke Krajenbrink and Kate M. Quinn, 'the adaptability of the genre is such that it can be used to affirm and also undermine all concepts of identity, be these at the level of nation, ethnicity, and culture or at the level of gender and genre ${ }^{6}{ }^{6}$ In this investigation into identity, the detective is central. For Timothy John Binyon, this figure reflects the social, political and cultural 
anxieties of the community he or she investigates by either conforming to or subverting them. ${ }^{7}$ An investigation into the detective's modus operandi, the way in which they interact with people, and how colleagues view them, is also an investigation into society and its cultural diversity. An analysis of the figure of the sleuth in Montalbán's and Thomas's crime fiction will highlight that their novels similarly reflect and reflect upon society and national identity.

In order to see how Spanish and New Zealand crime fiction mirror these issues, let us, first of all, briefly examine how Spanish and New Zealand detective fiction has changed throughout the last few decades. Critics claim that, historically, detective fiction took longer to catch on in Spain than in other European countries such as France, Italy or indeed England. The trajectory of the genre has been pieced together by the translations of pivotal works by the likes of Edgar Allan Poe, Emile Gaboriau and Fortuné du Boisgobey into European literatures. Poe was certainly being read in Spain in Baudelaire's French 1850s translation prior to the first Spanish translations of 1857 which, incidentally, were translations of Baudelaire's French versions and not of Poe's English original. Unlike elsewhere, these translations do not seem to have been very momentous. According to Renee Craig-Odders the first traces of the genre go back to 1853 with Pedro Alarcón's El clavo [The Nail]. ${ }^{8}$ Reprints of Gaboriau and du Boisgobey started to appear by the 1890s, as well as sporadic local titles such as, in 1898, La gota de sangre [The Drop of Blood], by Emilia Pardo Bazán. ${ }^{9}$ Not surprisingly, the rise of the detective story slowed down during the Franco years (1937-1975). Dictatorships have never cared much for foreign literature, even in translation. One curiosity of these years, however, is the vast number of Spanish pseudotranslations (that is, originals being presented as if they were translations) published during the time mainly imitating what appear to be hardboiled novels. This should not be unexpected given that the genre, particularly the hardboiled, lends itself to raising questions about social, ethical and political discontent. From the 1960s, however, as José Colmeiro points out, the role of translations published by Catalan publishers is crucial for the dissemination of a range of authors from Le Carré to Poe, from Doyle to Leblanc. ${ }^{10}$ With the liberalization of post-Franco Spain, the popularity of the detective story exploded, mainly in the form of the novela negra, or hardboiled fiction. And with it came Manuel Vázquez Montalbán whose work fuses the English whodunit with the American hardboiled in order to come to terms with Spain's turbulent political history and ambiguous place in European politics.

It is important to highlight the fact that during the almost forty years of his dictatorship, Franco tried to build a culturally and politically homogeneous society. Part of Franco's plan for creating a national identity 
was the unification of national symbols, anthems, and, of course, language. Such a scheme indeed obliterated all respect for the historical nations of Catalonia, the Basque country, and Galicia. In this way, national languages, icons and flags were all banned. This imposed a monolithic version of culture and history and, according to Mark Allinson, was reinforced by the erasing and subsequent reconstruction of a national identity through film. ${ }^{11}$ Thus, the regime created a discourse of Spanishness based on Castillian language and culture. After Franco's death, the novela negra reflects upon cultural and regional identities in Spain, claiming dignity and political recognition for the various Spanish regions. The fact that some of the most influential writers to emerge, such as Rafael Tasis, Manuel de Pedrolo, Maria Aurèlis Campany and Jaume Fuster, wrote in Catalan, not in Castillian/Spanish, is in itself significant. A large number of 'ethnic' or regional detectives who embody specific regional cultural habits were born. ${ }^{12}$ We will argue, though, that Carvalho is not quite an ethnic detective.

As regards New Zealand crime fiction, after the international success of the 'queen of crime' Ngaio Marsh (1895-1982), who mostly set the adventures of her sleuth, Roderick Alleyn, in Great Britain, local New Zealand crime fiction began to emerge in the 1960s. Written by Pākehā authors and very British in tone, it exploited the country's exotic setting to revitalize the cluepuzzle subgenre. ${ }^{13}$ Within this wave we find Valerie Merle Grayland who was the first -and only writer at the time -to introduce a Māori detective in her stories. ${ }^{14}$ After the boom of the 1960s and for the following two decades New Zealand writers mostly published abroad and set their works in overseas locales without engaging with their own local culture. A further wave of publication developed in the 1990s with small presses providing opportunities for crime writers who resumed the 1960s tradition of setting their stories in New Zealand. So far, among the most recent production set in contemporary New Zealand, only British-born Paul Thomas has written a series that features a Māori sleuth, Tito Ihaka.

The representation of Māori in New Zealand literature has changed throughout the years, reflecting the perspectives of a colonial society gradually transforming into an independent and multi-cultural country. In the early literature written by Pākehā, Māori were described in conventional ways, even if those conventions were at times contradictory. ${ }^{15}$ They were represented as mythological figures, both fascinating and threatening, as ethnological specimens, as inferior and shallow creatures, or as a dying species. ${ }^{16}$ Subsequently, indigenous voices were able to deliver representations of Māori and Māori culture through an insider's perspective. ${ }^{17}$ Stories from this point of view deconstructed persisting colonial stereotypes and represented a complex Māori identity. ${ }^{18}$ Finally, the most recent literature 
interrogates the many implications of an inescapably multi-cultural condition.

The representation of the indigene within the boundaries of a genre that highlights violence, crime and confrontation, may be predominantly insidious and subject to stereotypes. A Māori as a detective in a crime story written by a Pākehā writer is therefore a particularly interesting choice and serves as a showcase for the vital exercise of negotiating identities in a postcolonial context. Earlier New Zealand crime writers, like Grayland, describe Māori as stereotypical, good natives, and as naive, simple creatures onto whom these writers projected a manageable and enticing form of 'brownness'. Grayland's detective, Hoani Mata, for instance, never solves his cases alone, needing the help of an institutional policeman - and a Pākehā - Inspector Ted Plimsoll. Also, crime stories set in former colonies or settler societies often present the so-called 'postcolonial detective'. A postcolonial detective is an indigenous detective who has a different and successful approach to criminal investigations as a consequence of his or her cultural background. However, they are marginalized to the detriment of their ability to work at their full potential. ${ }^{19}$ While the intent of this characterization is probably benevolent, different but powerful stereotypes come into play, such as an alleged dichotomy between indigenous sensitivity and intuition and European rationality. We will argue that Thomas' Ihaka defies both the image of the happy indigene and the still wide-spread figure of the postcolonial detective.

\section{Vázquez Montalbán: reconciling regional identities}

Manuel Vázquez Montalbán (1939-2003) was born and bred in Barcelona, the setting for most of his novels. A poet, journalist, and script writer, Montalbán is perhaps best known outside Spain as a prolific novelist. His trademark was the incorporation of politics and social critique in popular culture. His first novel of the Carvalho series, Yo maté a Kennedy (1972 [I Killed Kennedy]) was published by Planeta after being censored by a Catalonian publisher Seix Barral. ${ }^{20}$ The Carvalho novels (twenty-two in total, the last being El hombre de mi vida (2000, [The Man of My Life, 2005]) have been translated into twenty-four languages, and five of them into English. Montalbán was awarded a number of prestigious prizes nationally and internationally, including the Planeta prize for Los mares del Sur (1978, [Southern Seas, 1988]) and the Raymond Chandler Award in 1992 for his contribution to the genre. ${ }^{21}$

As we mentioned, most of the Carvalho series is set within the microcosm of Barcelona. Carvalho, an ex-cop, ex-CIA operative, ex-Marxist and now private eye, operates with a 'Watson', Biscuter, and has a girlfriend, Charo, who is a prostitute. An obsessive gourmet, he devotes his time to 
the chasing of women and good food, the burning of canonical books he loves to hate in his fireplace, and getting paid in advance for cleaning up the 'dirty laundry' of the wealthy. The protagonist-detective has a special preoccupation with the interaction of the present with the past. Carvalho's investigations are situated in the context of Spanish and Catalan concerns with the post-Civil War and post-dictatorship recuperation of historical memory and the development and gentrification of Barcelona's Raval and Barri Xino districts that, in his opinion, dissolve the city's sense of history. Caragh Wells claims that, in the Carvalho novels, "the detective was ... a metaphor for the very dialectics of history: the constant dialogue between the present and the past that history generates. ${ }^{22}$

Although the Carvalho series presents a panoramic view of Catalan politics, history and culture, the detective's alliances defy a rigid interpretation of regional belonging as Carvalho himself identifies with a particular area of the city, rather than a region or nation. In the words of Stewart King, 'Carvalho is a Galician born in Barcelona and a Catalan who doesn't speak the language. His loyalty is not to any country or region but to the landscape of his childhood, Barcelona's Barrio Chino. ${ }^{23}$ Murder in the Central Committee, however, takes Carvalho on a murderous, gastronomic and cultural expedition 'abroad', to Madrid, where the General Secretary of the Communist Party has been killed. This 'foreign' locale serves as a platform to discuss questions of identities and loyalties, from the sleuth's own quest for the best place to eat the way you can only do 'back home' - Carvalho complains he is 'going to a town [Madrid] which had given no more than a stew, an omelette and a dish of tripe to the gastronomic culture of the country ${ }^{24}$ - to issues of political and historical importance such as the enquiry into the murder of a man whose political association was, not very long ago, under the Franco regime, illegal. For example, Salvatella, a member of the Spanish Communist Party, explains to Carvalho that he had to go 'underground until the Party was legalized in 1977. It's a pretty commonplace story in our party. 25

The clash of identities is made more evident as Carvalho faces a whole new world outside the comfort zone of his Barcelona. In Madrid, assistantcum-cook Biscuter is replaced by the good-looking but not 'traditionally educated' Carmela, a young communist who cannot cook and who represents the new post-Franco, independent Spanish woman. Through his investigation of the city (or cities as is the case here), Carvalho becomes Benjamin's classic flâneur figure; the 'unknown man who arranges his walk through [the city] in such a way that he always remains in the middle of the crowd. ${ }^{26}$ Thus, Montalbán exploits questions of identity in general and of belonging in particular. The fact that Carvalho is cruising the unfamiliar landscape of Madrid enhances the detective's cultural, gastronomic and geographical 
dislocation. At times Carmela treats Carvalho like an alien: 'Do you know where Machado is? Okay, I'll write down the address. It's very near the Santa Barbara Pub. You don't know that either? Where on earth are you from?'27

This idea of being a foreigner, of belonging or not to a particular region, is manifested in an apparent obsession of most characters to establish regional origin every time they engage in a conversation. For instance, throughout the novel, Carmela refers to Carvalho as a Catalan, an idea he sees as 'foreign' and always dismisses:

'Is the traffic this bad in Barcelona? You Catalans have a reputation as better drivers.' It was a long time since anyone had referred to him as Catalan. 'Barcelona's different - like Europe. Isn't that what they say?' 'I didn't think people said that anymore.' 'Oh yes! Particularly if you talk with a Catalan. I don't know why, but they do say it. ${ }^{28}$

As we can see from this passage, when referring to the Catalans, Carvalho always says 'they'. In this way, he differentiates himself from other Catalan detectives who proudly support the idea of a 'catalunydad' or 'Catalaness'. In fact, he does not see himself as coming from 'one' place; his regional identity seems to be much more complex: his surname is Portuguese, he was born in Galicia and he is an immigrant in Catalunya; therefore, his sense of identity is trans-regional and he rejects 'one-region' labelling. When American CIA agent, James Wonderful, asks Carvalho, 'I guess you haven't just come here to pay me a visit. Galicians never waste time. You are a Galician, aren't you?', Carvalho is quick to respond he is a 'cross-breed'. ${ }^{29}$

According to King, Montalbán 'criticizes a disproportionate focus on outward signs of cultural identification in Catalonia'..$^{30}$ On the one hand, this allows Montalbán to challenge the idea inherited from the regime that Spain is one nation, only Castillan Spanish, which resonates against the Francoist motto of 'España, una, grande y libre' ['Spain, One, Great and Free']. On the other hand, he equally makes fun of an excessive pride in regionalism:

'Have you people in Barcelona heard of Cigales wine? The only ones around here who ask for it are from Segovia or further north. It's no better than Rioja, but it's different. [. . .] Look, there are some very good wines in León. No, damn it, not in León, in El Biezo. This bloke is an El Bierzo separatist. [. . .] We moved from wine to autonomy statutes. Funny, but that often happens. One day Spain will be a federation of certified-origin wines. ${ }^{31}$

By bringing up questions of regional identity, Vázquez Montalbán is not only contributing to the undermining of the myth of cultural homogeneity inherited from the Franco years but he is also problematizing it further by making 
fun of an exacerbated obsession with regional identity. By being politically incorrect about this very sensitive topic the writer presents a middle path between Spanish and regional identities that highlight the complexity of the issue and the difficulty of establishing clear cut boundaries.

\section{Thomas: a new Māori detective}

Paul Thomas (1951) was born in England (Harrogate, Yorkshire), but grew up in New Zealand. He is a journalist, a writer and a sports biographer. His first crime novel is Old School Tie (aka Dirty Laundry, 1994). This was followed by Inside Dope (1995, which gained him the prestigious Australian Ned Kelly Award for Best Crime novel that year), and Guerrilla Season (1996). ${ }^{32}$ This series features Māori Sergeant Inspector Tito Ihaka as the main protagonist. Thomas' novels aim at being entertaining and can be considered as benevolent send-ups of the hardboiled sub-genre. The general tone is surreal, always over the top, consciously rude and not at all concerned with the good manners of classic detective fiction.

Old School Tie is the first book of the Ihaka trilogy. An alleged suicide of a businessman, Victor Appleyard - who plummets to his death from the Auckland harbour Bridge - triggers the investigation of a cold case involving the death of a teenage girl at an exclusive school ball twenty years before. Various people who attended the ball are suspects. They all are now in their late thirties and symbolize typical aspects of modernity: there is a lawyer who embodies the collapse of ethics in business; a former rock star who stands for the dark side of sex, drugs and rock and roll, and the end of 1970s innocence; a PR man, symbolizing the rise of the image industry, and so on. In the background there is a gang war that sees Kiwi criminals fighting against the Italian Mafia and the rising Asian Mob.

Ihaka, described as tall and solidly built, is a Sergeant Inspector in the Auckland police. Following convention in the hardboiled genre, he enjoys his drink. He is also tough, cynical and outspoken with a clear aversion for authority. He does not like to play according to the rules, but is respected for his ability to solve problems. However unorthodox his methods, Ihaka's competence is acknowledged by members of the public and colleagues and superiors alike. His investigation is muscular - as is typical of the hardboiled genre -and, unlike, the postcolonial detective, he does not make use of specific indigenous attributes to solve his crimes. Ihaka also moves in a modern, cosmopolitan society, where the physiognomy of the city, especially Auckland, has been transformed by a wave of immigration coming from the Pacific Islands, Asia and Europe.$^{33}$ Interestingly, in Old School Tie, Ihaka is described as Māori only in Chapter Ten, when a character, Louise Appleyard, sees 'the large Māori policeman whose name she couldn't remember' knocking at her door. ${ }^{34}$ Perhaps even more interesting is the fact that Ihaka 
does not associate himself with any particular Iwi or tribe, despite the fact that in Māori culture it is customary to acknowledge such affiliation. Like Carvalho, Ihaka goes beyond traditional labelling of his identity.

Aspects of Ihaka's Māoriness are only introduced later on in the novel. Appleyard thinks that '[T]here definitely was, she decided, a shrewd mind behind the immobile brown face'. ${ }^{35}$ The adjective 'brown' to describe Ihaka is used twice in this novel. The first time readers see the adjective brown is on page 66 as used by the narrator and the second time it is used by this character. By contrast, in the final pages of the book, Ihaka ironically describes himself as 'a fat boy' or refers to 'my black arse'. Furthermore: '[i]n Ihaka's opinion, one of the few direct benefits of being born brown was that one felt little compulsion to waste summer lying in the sun cultivating skin cancer, as Mrs Broome, whose complexion bore a resemblance to the skin of a passionfruit, obviously did. ${ }^{36}$ Being born brown is presented as a benefit in contrast to the foolishness of people with lighter complexions who waste their time (and possibly risk skin cancer) trying to be 'brown'. This point of view represents an overturning of old racist conventions, according to which having a darker skin is a disadvantage. In saying that, we refer in particular to Grayland, who, as mentioned, wrote a series in the 1960s with a Māori investigator. In Jest of Darkness (1965), a young woman called May says: 'That's the worst of being a Maori. You can't suddenly go blonde or something, ${ }^{37}$ as if being blonde -and fair skinned -is ultimately desirable. The contrast with the new 'brownness' embodied by Ihaka is striking.

The idea of Māoriness is addressed in several parts of this novel. Particularly interesting in this regard is a conversation between Ihaka and the vain PR executive Quedley:

'Didn't you use to play in the front row for University?' asked Quedley, examining him closely.

'Me? Shit no. You must be mixing me up with some other big coon.'

'Yes, well, a lot of you folk are impressive physical specimens, that's for sure,' said Quedley, undeterred by Ihaka's barely disguised truculence. 'It's something to do with the bones, isn't it?'38

As can be seen from this passage, the writer plays with a racist stereotype related to the physical strength of the Māori, or, more generally, to the physical power of the indigenous people often opposed to the alleged intellectual superiority of the colonizer. Quedley tries to flatter Ihaka talking about the physical strength of Māori - one of the aspects of representations of the Māori seen in early New Zealand literature written by Pākehā - but, as stated later on in the novel, the policeman is not impressed by Quedley's racist remark and dismisses his comment. Indeed, in Old School Tie, this image is not shared by the narrator who in fact uses this stereotype, clumsily 
articulated by Quedley, to portray this character as superficial. A few pages later, Ihaka meets Blair Corvine, an undercover policeman, who playfully refers to cannibalism, a practice of traditional Māori culture:

'That's Ihaka philosophy is it - if you can't fuck it or eat it, it's a waste of time? I guess it's difficult for someone whose great-grandfather was a cannibal to grasp the concept of aesthetic pleasure.'

'Watch yourself pal, I haven't had lunch. ${ }^{39}$

This time Ihaka ridicules the stereotype of the indigenous as threatening and primitive, one of the common images of Māori in early New Zealand literature. Throughout the novel, Ihaka feels comfortable in every situation and with all sorts of people. He is not different -and he does not feel marginalized. Being Māori does not have consequences for his ability to work at full potential and to be recognized as an authority. Consequently, he is very different from the typical postcolonial detective.

In the same conversation with Corvine, Ihaka is also very assertive about the land dispute in New Zealand:

'Hey, it's big chief Ihaka,' he said. 'You and the bros dispossessed any hard-working honkies lately?'

'Well, my man, the fight for justice is never-ending. I tell you what, they wear you down those pakehas, bleating about how their family's been there for 150 years and how they've levelled hills and cleared a thousand acres of bush and all this shit. You wouldn't believe the crap we have to put up with. Christ, we're not unreasonable people; we let you stay here - what more do you want?'

'I'd settle for not having that oily heap of shit with the tiki on TV every other night.'

'I'm afraid you'll have to be more specific. ${ }^{40}$

This passage is particularly interesting because there is a reversal of perspective. Here there is no debate of Māori land rights, but rather a mockery of the rights of colonizers. Moreover, in making fun of a hot topic in recent New Zealand history Thomas, like Vázquez Montalbán, invites readers to see things differently.

Ultimately, Ihaka is neither the subservient Māori nor the 'savage' and threatening indigene. He can get drunk, but he can also hold a civilized conversation. Thus, he defies both the patronizing image of the Māori seen in previous New Zealand crime fiction and the idea of the postcolonial detective, typical of the genre. Thomas may not show particular originality in portraying the lonely, anti-social, almost alcoholic detective who knows his way around pimps, informants and junkies, but in doing so he does 
conform to the generic tendencies of the hardboiled and does not confine his detective to a 'special' indigenous category.

\section{Conclusion}

Both Carvalho and Ihaka fail to conform to conventions of the stereotypical ethnic and postcolonial detectives respectively. Carvalho is comfortable in his local turf of the Barri Xino in Barcelona, but is himself Galician by birth and name, and Catalan by choice. In The Man of My Life, Carvalho confesses that one-region labels are obsolete: 'What is clear to me is that I am not a nation. I find it difficult enough to be an individual and I have no trust in a people. Individuals can have compassion, a people cannot. Being a nation would complicate my life too much. ${ }^{41}$ Nor does Ihaka see himself as a disadvantaged person. He is tough, outspoken and makes fun of stereotypes and clichés about Māori.

In conclusion, by 'refusing' the roles of ethnic or postcolonial detectives Vázquez Montalbán and Thomas invite their readers to question their own polarized assumptions about cultural identities via the figure of the detective. In the final analysis, they expose the contemporary discourse on cultural identities, both in Spain and New Zealand, to new interpretations.

1 Manuel Vázquez Montalbán, Asesinato en el Comité Central, Barcelona, 1981, Murder in the Central Committee, tr. Patrick Camiller, London, 1984.

2 Paul Thomas, Old School Tie, Auckland, 1994.

3 We will be referring to the subgenre of the British whodunit and the American hardboiled, which in broad terms sit at opposite ends of the spectrum. The whodunit is mainly associated with rural England in the 1920s. The hardboiled tradition, on the other hand, features a strong element of urban realism (set in cities like Los Angeles, Chicago, New York) and middle-class voyeurism of the 'low life'. For a thorough history of the genre, particularly strong on British and American perspective, see Julian Simon, Bloody Murder: From Detective Story to the Crime Novel, New York, 1995, and Colin Watson, Snobbery with Violence, English Crime Stories and their Audience, London, 1971.

4 Pākehā: 'A fair-skinned non-Polynesian immigrant to New Zealand'. As an adjective it is used to refer to Europeans (as distinct from Māori). E. and H. Orsman, Dictionary of New Zealand, Auckland, 1994, p.193.

5 Margaret Crawford, 'Investigating the City - Detective Fiction as Urban Interpretations: Reply to M. Christine Boyer,' in D. Agrest, P. Conway and L. Kanes Weisman, eds, The Sex of Architecture, New York, 1996, p.119-27, p.120.

6 M. Krajenbrink and K.M. Quinn, eds, Investigating Identities. Questions of Identity in Contemporary International Crime Fiction, Amsterdam/New York, 2009, p.1.

7 Timothy John Binyon, Murder Will Out. The Detective in Fiction, Oxford, 1990, p.1.

8 Renée Craig-Odders, The Detective Novel in Post-Franco Spain: Democracy, Disillusionment, and Beyond, New Orleans, 1999, p.11. 
9 Pardo Bazán's La gota de sangre was published between 1893 and 1898. Her nouvelle could be considered a pastiche of Conan Doyle's Sherlock Holmes series as it features a Holmes-type detective.

10 José F. Colmeiro, La novela policiaca española: teoría e historia crítica, Barcelona, 1994, p.169.

11 Mark Allinson, A Spanish Labyrinth: The Films of Pedro Almodóvar, London, 2001.

12 Tasis wrote three detective novels in the immediate post-war period: La Biblia valenciana, Un crim paralelo (both in 1944) and És hora de plegar (1955). Pedrolo's most influential titles are: És vessa una sang fácil (1952 published in 1955), L'inspector fa tard (1953, translated as Juego sucio, 1972), and Mossegar-se la cua (1968, translated as Morderse la cola, 1975). Pedrolo was also director of the series La Cua de palla (1963-70) 'consisting of Catalan translations of seventy-one detective stories' (Craig-Odders, p.18-19). Other writers emerging after Pedrolo and also publishing in Catalan are Ramon Planes, Lloenç Capellà and Sierra I Fabra.

13 Joan Stevens, The New Zealand Novel. 1860-1965, Auckland, 1966, p.115.

14 Grayland wrote a series of detective fiction novels which include The Dead Man of Eden (1962), The Night of the Reaper (1963), The Grave-Digger's Apprentice (1964), and Jest of Darkness (1965).

15 Jane Stafford and Mark Williams, Maoriland: New Zealand Literature 1872-1914, Wellington, 2006, p.10.

16 Leonard Bell, Colonial Construct: European Images of Maori 1840-1914, Auckland, 1992, p.3.

17 Sarah Shieff, 'Where's Waari? A History of the Maori through the Short Story', in S. Ryan-Fazilleau, ed., New Zealand and Australia: Narrative, History, Representation, London, 2008, pp.5-22.

18 Bill Pearson, 'The Maori and Literature 1938-65', in W. Curnow, ed., Essays on New Zealand Literature, Auckland, 1973, pp.99-138.

19 The Post-Colonial Detective, E. Christian, ed., New York, 2001.

20 Manuel Vázquez Montalbán, Yo maté a Kennedy, Barcelona, 1972.

21 The Carvalho series was also translated onto the screen, both cinema and television: Tatuaje (1976, Profilmar/Spain, dir. J.J Bigas Luna), Asesinato en el comité central (1982, Spain, dir. J.J. Bigas Lunas), and Los mares del sur (1990, Cyrkfilms/I.C.C./ Spain, dir. Manuel Esteban) were made into films. On television, there were two series of the Carvalho saga: Las aventuras de Pepe Carvalho (1984-85, Spain/France, dirs. Adolfo Aristarian, José Luis Cuerda, and José Antonio Pàramo), and Pepe Carvalho (1998-1999, CARTEL, dirs. Enrique Urbizu, Merzak Allouache, Emmanuelle Cuau, Franco Giraldi).

22 C. Wells, 'The Case of Barcelona in Manuel Vázquez Montalbán's Detective Fiction', Romance Studies, 25, 4 (2007), pp.279-88, p.286.

23 Stewart King, 'Articulating and Disarticulating Culture' in M. Krajenbrink and K.M.Quinn, eds, Investigating Identities. Questions of Identity in Contemporary International Crime Fiction, Amsterdam/New York, 2009, pp.27-42, p.31.

24 Vázquez Montalbán, Asesinato, p.19.

25 Ibid., p.28.

26 Walter Benjamin, Charles Baudelaire: A Lyric Poet in the Era of High Capitalism, London, 1983, p.48. 


\section{Journal of New Zealand Studies}

27 Vázquez Montalbán, Asesinato, p.58.

28 Ibid., p.34.

29 Ibid., p.83.

30 King, p.31.

31 Vázquez Montalbán, Asesinato, p.144.

32 Thomas also published other novels: Star Struck (1999-2000), Final Cut (1999), The Empty Bed (2002), Work in Progress (2006) and a short story collection, Sex Crimes (2003).

33 The ethnic make-up of the population has changed in the last decades. In 2001 the Pākehā majority formed $73 \%$ of the population, people of Māori descent accounted for 18.4\%, while New Zealand Asians made up 6\%, and Pacific Islanders 4.6\%. See Michael King, The Penguin History of New Zealand, Auckland, 2003, p.499.

34 Thomas, Old School, p.113.

35 Ibid., p.117.

36 Ibid., p.64.

37 Grayland, Jest of Darkness, p.111.

38 Thomas, Old School, p.227.

39 Ibid., p.230.

40 Ibid., p.229.

41 Manuel Vázquez Montalbán, El hombre de mi vida, Barcelona, 2000 (The Man of My Life, tr. Nick Caistor, London, 2005, p.22). 